\title{
Post-Operative Chronic Pain Control in Mediastinal Lymphomas in An Elderly Population: the Role of Physical Activity
}

Antonello Sica ${ }^{1}, \uparrow$, Beniamino Casale ${ }^{2}, \dagger$, Caterina Sagnelli ${ }^{3, \dagger}$, Armando Calogero ${ }^{4}$, Maria Teresa Di Dato $^{5}$, Alessandro Spada ${ }^{1}$, Marco Rispoli $^{5}$, Mario Santagata ${ }^{6}$, Pietro Buonavolontà ${ }^{5}$, Alfonso Fiorelli ${ }^{7}$, Vincenzo Tammaro ${ }^{4}$, Massimo Ciccozzi $^{8}$, Anna Salzano $^{5}$, Evangelista Sagnelli ${ }^{3}$, Elisabetta Saracco ${ }^{5}$, Dario Tammaro ${ }^{5}$, Alfonso Papa ${ }^{5}$

1. Department of Precision Medicine, University of Campania Luigi Vanvitelli, Naples, Italy.

2. Department of Pneumology and Tisiology, AO Dei Colli - V. Monaldi, Naples, Italy.

3. Department of Mental Health and Public Medicine, University of Campania Luigi Vanvitelli, Naples, Italy.

4. Department of Advanced Biomedical Sciences, University of Naples Federico II, Naples, Italy.

5. Pain Department, AO Dei Colli - V. Monaldi, Naples, Italy.

6. Multidisciplinary Department of Medical Surgery and Dental Specialties, University of Campania Luigi Vanvitelli, Naples, Italy.

7. Thoracic Surgery Unit University of Campania Luigi Vanvitelli, Naples, Italy.

8. Medical Statistics and Epidemiology, Campus Bio-Medico University, Rome, Italy.

\section{$\dagger$ : Equal contribution to the work.}

Short title: Sport training in elderly patients with Post-operative pain

Corresponder author: Dr. Antonello Sica, Department of Precision Medicine, University of Campania Luigi Vanvitelli, Naples, Italy, 80131, Tel: +393332253315, +3908119573375, e-mail: antonellosica@gmail.com

Conflict-of-interest statement: All the authors of the manuscript declare they have no conflict of interest in connection with this paper.

Competing Interests: The authors have declared that no competing interests exist.

\section{Abstract}

Thoracotomy is one of the most painful types of incision a patient can experience. Pain is a very complex pathophysiological entity. Neuronal pathophysiological mechanisms are integrated 
with the immunological response, which amplify inflammation and pain. Prolonged inflammation induces a pathological response of the immune-system and constantly stimulate the nociceptive pathways generating chronic pain. The mechanisms are particularly altered in lymphomas, where pain following chest surgery often becomes chronic and reduces the quality of life.

In this study 51 elderly patients who had undergone a transthoracic biopsy to verify the suspect of mediastinal lymphoma were examined for pain reduction with oral opioids, effect of epidural analgesia and paravertebral block. Subsequently, patients underwent tensed torsion exercises, progressively intensified. After the first few days, patients walked progressively for 20 minutes a day. Once discharged a program of patients started aerobic exercises to increase muscle endurance and to strengthen the extensor muscles of the legs and of the upper limbs.

The systemic administration of opioids is the simplest and most common method of providing analgesia for postoperative pain, but early mobilization, respiratory rehabilitation, and muscle toning exercises are excellent support devices both for physical and psychological recovery.

Keywords: physical activity; elderly population; chronic pain; mediastinal lymphomas 


\section{Introduction}

Thoracotomy can be one of the most painful types of incision a patient can experience [1]. Pain can inhibit effective coughing, deep breathing and limit early postoperative loosening [2]. As a result, lung ventilation may not be optimal, with an increased risk of lung infections, this is emphasized with advancing age [4]. In addition, inadequate postoperative pain management may contribute to the development of a chronic post-thoractomy pain syndrome [5]. Therefore, the clinicians should maintain an analgesic regimen providing pain relief and consequently the ability to maintain their residual functional capacity through deep breathing [6]. Indeed, an effective elimination of secretions by coughing and early mobilization can lead to faster recovery and to a shorter hospital stay. Pain is a very complex pathophysiological entity, which does not depend exclusively on trauma, but often it has multiple etiologies especially in elderly patients with lymphomas or other neoplasms. Prolonged inflammation induces a pathological response that persists beyond the recovery, constantly stimulating the nociceptive pathways and thus generating chronic pain [7-10]. Neuronal pathophysiological mechanisms are integrated with the immunological response [10-12], the overproduction of cytokines such as IL-6, TNF- $\alpha$, IL1- $\beta$ by macrophages and monocytes which amplify inflammation and pain. Instead, both activated B and T lymphocytes have an inhibitory action on pain for the production of IL-10, the cytokine with the highest inhibitory action on the secretion of IL-1 $\beta$, IL-6 and TNF- $\alpha$ [13-15]. Especially in lymphomas, but also in other neoplasms, the mechanisms involving these cells are altered, helping to not amplify neuropathic pain [16-20]. It is evident that the complexity of the pathogenesis of neuropathic pain does not allow unambiguous solutions in these patients who should be mobilized immediately after surgical procedures [21]. As soon as they are able to, they should undergo tensed torsion exercises which should be progressively intensified. After the first few days, walks should be progressively faster for 20 minutes a day [22-23]. Once discharged, aerobic exercise to increase muscle endurance, and to strengthen the extensor muscles of the legs and of the upper limbs are recommended [24-26]. Early mobilization and small exercises promote respiratory function, contrast the inflammatory mechanisms described above and lower the sensation of pain; another fundamental role, especially in patients with upper caval syndrome, is the support to the lymphatic drainage and to the antithrombotic prophylaxis [27-28]. The systemic administration of opioids is the simplest and most common method of providing analgesia for postoperative pain, but it can be associated with several side effects, such as respiratory depression, sedation, nausea and vomiting. Epidural thoracic analgesia is commonly considered the gold standard to limit the post-operative pain after thoracotomy but in some cases this technique may fail or it may be contraindicated. In fact, epidural analgesia has been found associated with complications like hypotension, epidural hematoma, nerve injury, and shoulder pain at the 
ipsilateral side of the incision [28-29]. The origin of this pain has not been completely elucidated and additional methods of postoperative pain control are considered of enormous interest [30-32].

In our study 51 elderly patients who had undergone a transthoracic biopsy to verify one suspect of mediastinal lymphoma were examined for pain reduction with oral opioids, effect of epidural analgesia and paravertebral block [33-36].

\section{Materials and Methods}

Our study samples consist of 51 consecutive patients, aged 57 - 84 years who underwent transthoracic biopsy for suspected mediastinal lymphoma, from January 2017 to October 2019, at the Pain Department, AO Dei Colli, Naples, Italy. All clinical procedures were performed in accordance with international guidelines, the standards of human experimentation of the local Ethics Committees and with the Helsinki Declaration of 1975, revised in 1983. At the baseline visit, each patient signed a informed consent for the use of their data in clinical investigation, according with the Italian lows on privacy and underwent a complete physical examination. Their thoracic pain was evaluated with the McGill Pain Questionnaire (MPQ), recording the Numerical Rating Scale (NRS) of average pain: minimum pain, maximum pain and pain during exertion (scale 0-10: $0=$ no pain, $10=$ worst pain ever). Patients were also tested for $\mathrm{HBsAg}$, anti-HCV, total anti-HBc, and anti-hepatitis B surface antibody (HBs) using specific commercial immunoenzymatic assays as described in previous studies [37-41]. All 51 patients underwent tensed torsion exercises, progressively intensified. After the first few days, patients walked progressively for 20 minutes a day. Once discharged a program of patients started aerobic exercises to increase muscle endurance and to strengthen the extensor muscles of the legs and of the upper limbs.

\section{Results}

The demographic and clinical data obtained at the enrolment are shown in Table 1 and 2. The 51 patients were predominantly male 34 (67\%), with a median age of 68.12 years (range: $57-84)$. Of those 51, 17 patients underwent to a thoracotomy and 34 patients Video-Assisted Thoracoscopic Surgery (VATS). The intensity of pain after the surgical procedure was very intense (NRS:10) for only one patient, 9 patients had NRS 8, 25 NRS 6, 10 NRS 1, for the remaining 6 the NRS was not detected. The patient with NRS 10 had undergone a VATS and was treated with systemic opioids analgesia during hospitalization. Of the 9 patients with NRS 8,7 had been treated with systemic 
opioids ( 2 received VATS and 5 thoracotomy and 2 were treated with PVB both with VATS biopsy). Of the 25 patients with NRS 6, 16 had been treated with systemic opioids of which 8 had undergone VATS and 8 thoracotomy; 5 had been treated with PVB (all had undergone a biopsy with VATS) and 4 with TEA of which 3 with a thoracotomy and 1 with VATS.

\section{Discussion and Conclusions}

Pain following chest surgery often becomes chronic and reduces the quality of life. Scar pain is a complex entity of multifactorial origin present also in minimally invasive surgery. Early mobilization, respiratory rehabilitation, and muscle toning exercises are excellent support devices both for physical and psychological recovery, since they play an action on the reduction of inflammation, improve the quality of life and give optimism to elderly patient who always lives with particular concern for the onset of a new illness. Epidural thoracic analgesia is considered the best postoperative pain therapy after thoracotomy, but when this technique is contraindicated or fails it should look for other innovative or pioneering solutions.

\section{Appendix}

Table.1 Patient treated with systemic opioids analgesy after biopsy.

\begin{tabular}{|c|c|c|c|}
\hline $\begin{array}{c}\text { Age } \\
\text { (years) }\end{array}$ & Sex & $\begin{array}{c}\text { Pain } \\
\text { relief (NRS) }\end{array}$ \\
\hline 64 & F & THORACHOTOMY & 8 \\
\hline 80 & M & THORACHOTOMY & 6 \\
\hline 69 & M & VATS & 6 \\
\hline 84 & M & VATS & 1 \\
\hline 74 & F & VATS & 6 \\
\hline 77 & F & VATS & 8 \\
\hline 77 & M & VATS & 1 \\
\hline 58 & M & VATS & 8 \\
\hline 60 & M & VATS & 6 \\
\hline 59 & F & VATS & 6 \\
\hline 61 & F & VATS & 1 \\
\hline 76 & M & VATS & \\
\hline 65 & M & VATS & 8 \\
\hline & & & \\
\hline
\end{tabular}




\begin{tabular}{|c|c|c|c|}
\hline 62 & $\mathrm{M}$ & THORACHOTOMY & 6 \\
\hline 57 & M & VATS & 6 \\
\hline 59 & $\mathrm{M}$ & THORACHOTOMY & 6 \\
\hline 59 & M & THORACHOTOMY & 6 \\
\hline 76 & $\mathrm{M}$ & VATS & 1 \\
\hline 71 & $\mathrm{M}$ & VATS & 1 \\
\hline 71 & M & THORACHOTOMY & 6 \\
\hline 71 & $\mathrm{~F}$ & THORACHOTOMY & 6 \\
\hline 70 & $\mathrm{M}$ & VATS & 1 \\
\hline 61 & $\mathrm{M}$ & THORACHOTOMY & 6 \\
\hline 70 & $\mathrm{M}$ & VATS & 6 \\
\hline 72 & $\mathrm{~F}$ & VATS & N.D. \\
\hline 70 & $\mathrm{~F}$ & VATS & 6 \\
\hline 80 & $\mathrm{~F}$ & VATS & 8 \\
\hline 70 & $\mathrm{M}$ & VATS & N.D. \\
\hline 64 & $\mathrm{~F}$ & THORACHOTOMY & 8 \\
\hline 80 & $\mathrm{M}$ & THORACHOTOMY & 6 \\
\hline 69 & M & VATS & 6 \\
\hline 84 & $\mathrm{M}$ & VATS & 1 \\
\hline 74 & $\mathrm{~F}$ & VATS & 10 \\
\hline
\end{tabular}

Video-Assisted Thoracoscopic Surgery (VATS)

Table 2 Patient treated with PVB or TEA after biopsy.

\begin{tabular}{|c|c|c|c|c|}
\hline $\begin{array}{c}\text { Age } \\
\text { (years) }\end{array}$ & Sex & Surgery type & PVB/TEA & $\begin{array}{c}\text { Pain relief } \\
(\mathbf{N R S}) \mathbf{( 0 - 1 0})\end{array}$ \\
\hline 73 & $\mathrm{M}$ & THORACHOTOMY & TEA & N.D. \\
\hline 73 & $\mathrm{M}$ & VATS & PVB & 6 \\
\hline 64 & $\mathrm{~F}$ & VATS & PVB & 8 \\
\hline 57 & $\mathrm{~F}$ & VATS & PVB & N.D. \\
\hline 68 & F & VATS & PVB & 1 \\
\hline
\end{tabular}




\begin{tabular}{|c|l|l|l|l|}
\hline 72 & M & VATS & PVB & 6 \\
\hline 62 & $\mathrm{~F}$ & VATS & TEA & \multicolumn{1}{|c|}{ PVB } \\
\hline 80 & $\mathrm{M}$ & VATS & TEA & 6 \\
\hline 57 & $\mathrm{M}$ & THORACHOTOMY & TEA & N.D. \\
\hline 60 & $\mathrm{~F}$ & VATS & PVB & 6 \\
\hline 64 & $\mathrm{~F}$ & VATS & PVB & 6 \\
\hline 60 & $\mathrm{~F}$ & THORACHOTOMY & PVB & 6 \\
\hline 67 & $\mathrm{~F}$ & VATS & PVB & 8 \\
\hline 64 & $\mathrm{M}$ & THORACHOTOMY & PVB & 6 \\
\hline 62 & $\mathrm{M}$ & VATS & TEA & 6 \\
\hline 61 & $\mathrm{M}$ & VATS & TEA & 6 \\
\hline 68 & $\mathrm{M}$ & THORACHOTOMY & THORACHOTOMY & \\
\hline
\end{tabular}

Video-Assisted Thoracoscopic Surgery (VATS)

\section{References}

1. Kehlet, H.; Jensen, T.S.; Woolf, CJ. The mechanism of post-thoracotomy pain syndrome (PTPS). Lancet. 2006;367:1618-25.

2. Rogers, M.L.; Duffy, J.P. Surgical aspect of chronic post-thoracotomy pain. Eur J Cardiothorac Surg. 2000;18:711-16.

3. Kim, W.; Jesper, R.; Henrik, K. Chronic post-thoracotomy pain: a critical review of pathogenic mechanism and strategies for prevention. Eur J Cardiothorac Surg. 2009;36:17080.

4. Peng, Z.; Li, H.; Zhang, C.; Qian, X.; Feng.; Z, Zhu, S. A retrospective study of chronic post-surgical pain following thoracic surgery: prevalence, risk factors, incidence of neuropathic component, and impact on qualify of life. PLOS ONE. 2014;9(2):e90014.

5. Maxwell, C.; Nicoara, A. New developments in the treatment of acute pain after thoracic surgery. Curr Opin Anaesthesiol. 2014;27(1):6-11.

6. Gerner, P. Post-thoracotomy Pain Management Problems. Anesthesiol Clin. 2008;26(2):355-vii. 
7. Sica, A.; Casale, B.; Di Dato, MT.; Calogero, A.; Spada, A.; Sagnelli, C.; et al. Cancer and not cancer related chronic pain: from the physiopathological bases to the management. Open Med (Wars). 2019;14:761-766. DOI: 10.1515/med-2019-0088.

8. de Miguel, M.; Kraychete, D.C.; Meyer Nascimento, R.J. Chronic pain: cytokines, lymphocytes and chemokines. Inflamm Allergy Drug Targets. 2014;13(5):339-49.

9. Scholz, J.; Woolf, CJ. The neuropathic pain triad: neurons, immune cells and glia. Nature Neurosci. 2007;10(11):1361-1368.

10. Zhang, J.M.; An, J. Cytokines, inflammation, and pain. Int Anesthesiol Clin. 2007;45:27-37.

11. Basbaum, A.I.; Bautista, D.M.;Scherrer, G.; Julius, D. Cellular and molecular mechanisms of pain. Cell. 2009;139:267-84.

12. Uçeyler, N.; Rogausch, J.P.; Toyka KV.; Sommer C. Differential expression of cytokines in painful and painless neuropathies. Neurology. 2007;69(1):42-9.

13. Uçeyler, N.; Eberle, T.; Rolke, R.; Birklein, F.;Sommer C. Differential expression patterns of cytokines in complex regional pain syndrome. Pain. 2007;132(1-2):195-205.

14. Koch, A.; Zacharowski, K.; Boehm, O.; Stevens, M.; Lipfert, P.; von Giesen, H.J.; et al. Nitric oxide and pro-inflammatory cytokines correlate with pain intensity in chronic pain patients. Inflamm Res. 2007;56(1):32-7.

15. Sandkühler, J.; Gruber-Schoffnegger, D. Hyperalgesia by synaptic long-term potentiation (LTP): an update. Curr. Opin. Pharmacol. 2012;12(1):18-27.

16. Reginelli, A.; Belfiore M.P.; Russo, A.; Turriziani, F. ; Moscarella, E. ; Troiani, T. ; Brancaccio G., Ronchi, A., Giunta, E., Sica A., Iovino, F., Ciardiello, F., Franco, R., Argenziano, G., Grassi R., Cappabianca, S. A preliminary study for quantitative assessment with HFUS (High Frequency ultrasound) of nodular skin melanoma Breslow thickness in adults before surgery: Interdisciplinary team experience. Curr Radiopharm. 2019. DOI: $10.2174 / 1874471012666191007121626$.

17. Gruber-Schoffnegger, D.; Drdla-Schutting, R.; Hönigsperger, C.; Wunderbaldinger, G.; Gassner, M.; Sandkühler, J. Induction of thermal hyperalgesia and synaptic long-term potentiation in the spinal cord lamina I by TNF- $\alpha$ and IL-1 $\beta$ is mediated by glial cells. $J$. Neurosci. 2013;33(15):6540-6551. 
18. Thacker, M.A.; Clark, A.K.; Marchand, F.; McMahon, S.B. Pathophysiology of peripheral neuropathic pain: immune cells and molecules. Anesth Analg. 2007;105(3):83847.

19. Merskey, H.; Bogduk, N. Classification of chronic pain. 2nd ed. Seattle: IASP Press, 1994. p. 1 .

20. Sica, A.; Vitiello, P.; Sorriento, A.; Ronchi, A.; Calogero, A.; Sagnelli, C.; Troiani, T.; Fasano, M.; Dodaro C.A.; Franco, R.; Casale, B.; Santangelo, M.; Ciccozzi, M.; Ciardiello, F.; Argenziano, G.; Moscarella, E. Lymphomatoid papulosis. Minerva Medica. In press 21. Treede, R.D.; Rief, W.; Barke, A.; Aziz, Q.; Bennett, M.I.; Benoliel, R.; et al. A classification of chronic pain for ICD-11. Pain. 2015;156(6):1003-7. DOI: 10.1097/j.pain.0000000000000160.

22. Breivik H, Collett B, Ventafridda V, Cohen R, Gallacher D. Survey of chronic pain in Europe: prevalence, impact on daily life, and treatment. Eur J Pain. 2006;10:287.

23. Vellucci, R. Heterogeneity of chronic pain. Clin Drug Investig. 2012;32(Suppl 1):310.

24. Calogero, A.; Sagnelli, C.; Carlomagno, N.; Tammaro, V.; Candida, M.; Vernillo, A.; Peluso, G.; Minieri, G.; Santangelo, M.; Dodaro, C.A.; et al. Familial polyposis coli: The management of desmoid tumor bleeding. Open Med (Wars). 2019;14:572-576. DOI: 10.1515/med-2019-0064.

25. Oldervoll, L.M.; Kaasa, S., Knobel, H.; Loge, J.H. Exercise reduces fatigue in chronic fatigued Hodgkins disease survivors—Results from a pilot study. Eur. J. Cancer. 2003;39:5763. DOI: 10.1016/S0959-8049(02)00483-5.

26. Cramp, F.A.; Byron-Daniel, J.Z. Exercise for the management of cancer related fatigue in adults. Cochrane Database Syst. Rev. 2012;11 DOI: 10.1002/14651858.CD006145.pub3.

27. Knols, R.; Aaronson, N.K.; Uebelhart, D.; Fransen, J.; Aufdemkampe, G. Physical exercise in cancer patients during and after medical treatment: A systematic review of randomized and controlled clinical trials. J. Clin. Oncol. 2005;23:3830-3842. DOI: 10.1200/JCO.2005.02.148.

28. Sica, A.; Casale, B.; Spada, A.; Di Dato, M.T.; Sagnelli, C.; Calogero, A.; Buonavolontà, P.; Salzano, A.; Martinelli, E.; Saracco, E.; Troiani, T.; Dodaro, C.A.; 
Tammaro, D.; De Rimini, M.L.; Ciardiello, F.; Papa A. Differential diagnosis: retroperitoneal fibrosis and oncological diseases. Open Med (Wars). DOI: 10.1515/med-2020-0005.

29. Caccavale, S.; Vitiello, P.; Franco, R.; Panarese, I.; Ronchi, A.; Sica, A.; Jurakic, T.R.; Alfano, R.; Argenziano, G. Dermoscopic characterization of folliculotropic mycosis fungoides selectively localized on trunk and limbs. Int J Dermatol. 2019;58(10):e187-e189. DOI: $10.1111 /$ ijd.14490.

30. Blair, C.K.; Morey, M.C.; Desmond, R.A.; Cohen, H.J.; Sloane, R.; Snyder, D.C.; Demark-Wahnefried, W. Light-intensity activity attenuates functional decline in older cancer survivors. Med. Sci. Sports Exerc. 2014;46:1375. DOI: 10.1249/MSS.0000000000000241.

31. Craig, C.L.; Marshall, A.L.; Sjostrom, M.; et al. International physical activity questionnaire: 12-country reliability and validity. Med Sci Sports Exerc 2003; 35:1381e95.

32. Van den Beuken-van Everdingen, M.; de Rijke, J.; Kessels, A.; Schouten, H.; van Kleef, M.; Patijn, J. Prevalence of pain in patients with cancer: a systematic review of the past 40 years. Annals of Oncology. 2007;18(9):1437-1449. DOI: 10.1093/annonc/mdm056.

33. Inoue, S, Kobayashi, F, Nishihara, M, Arai, Y.C, Ikemoto, T, Kawai, T, et al. Chronic pain in the Japanese community-prevalence, characteristics and impact on quality of life. PLoS One. 2015;10(6). DOI: 10.1371/journal.pone.0129262.e0129262.

34. Finnerup, N.B.; Attal, N.; Haroutounian, S.; et al. Pharmacotherapy for neuropathic pain in adults: a systematic review and meta-analysis. Lancet Neurol. 2015;14:162-173.

35. Yarchoan, M.; Naidoo, J.; Smith, T.J. Successful Treatment of Scar Pain with Scrambler Therapy. Cureus. 2019;11(10):e5903. DOI: 10.7759/cureus.5903.

36. Sica, A.; Vitiello, P.; Papa, A.; Calogero, A.; Sagnelli, C.; Casale, D.; Mottola, M.; Svanera, G.; Dodaro, C.A.; Martinelli, E.; Troiani, T.; Ciardiello, F.; Casale, B. Use of rituximab in NHL malt type pregnant in $\mathrm{I}^{\circ}$ trimester for two times. Open Med (Wars). 2019; 14:757-760. DOI: 10.1515/med-2019-0087.

37. Pisaturo, M.; Guastafierro, S.; Filippini, P.; Tonziello, G.; Sica, A.; Di Martino, F.; et al. Absence of occult HCV infection in patients experiencing an immunodepression condition. Infez Med. 2013;21(4):296-301.

38. Tonziello, G.; Pisaturo, M.; Sica, A.; Ferrara, M.G.; Sagnelli, C.; Pasquale, G.; et al. Transient reactivation of occult hepatitis B virus infection despite lamivudine prophylaxis in 
a patient treated for non-Hodgkin lymphoma. Infection. 2013;41(1):225-9. DOI: 10.1007/s15010-012-0305-y.

39. Coppola, N.; Pisaturo, M.; Guastafierro, S.; Tonziello, G.; Sica, A.; Iodice, V.; et al. Increased hepatitis C viral load and reactivation of liver disease in HCV RNA-positive patients with onco-haematological disease undergoing chemotherapy. Dig Liver Dis. 2012;44(1):49-54. DOI: 10.1016/j.dld.2011.07.016.

40. Coppola, N.; Pisaturo, M.; Guastafierro, S.; Tonziello, G.; Sica, A.; Sagnelli, C.; et al. Absence of occult hepatitis $\mathrm{C}$ virus infection in patients under immunosupressive therapy for oncohematological diseases. Hepatology. 2011;54(4):1487-9. DOI: 10.1002/hep.24436.

41. Merli, M.; Frigeni, M.; Alric, L.; Visco, C.; Besson, C.; Mannelli, L.; et al. DirectActing Antivirals in Hepatitis C Virus-Associated Diffuse Large B-cell Lymphomas. Oncologist. 2019; 24(8):e720-e729. DOI: 10.1634/theoncologist.2018-0331. 